\title{
Analisis Mekanisme Penggunaan Kendaraan Operasional Pada Kantor Sekretariat Daerah Kota Gorontalo
}

\author{
Nuzlan Botutihe \\ Program Studi Administrasi Publik Fakultas Ekonomi dan Ilmu Sosial \\ Universitas Muhammadiyah Gorontalo, Gorontalo Indonesia \\ Email : nuzlan1979@gmail.com
}

\begin{abstract}
This study aims to determine the mechanism of operational vehicle use at the Office of the Regional Secretariat of Gorontalo City and Identify what efforts are made Regional Secretariat Office of Gorontalo. The research approach used is quantitative and supported by primary data and secondary data. The result of research shows that: 1) Mechanism of utilization of operational vehicle in Regional Secretariat Office of Gorontalo reaches 78,33\%. 2) The operational vehicle lending mechanism within the Office of the Regional Secretariat of Gorontalo City has not produced satisfactory results. 3) Referring to the average achievement of $68.06 \%$, it can be interpreted that the operational vehicle financing mechanism within the Office of the Regional Secretariat of Gorontalo City has not been as effective and as efficient as expected. 4) Reviewing the average acquisition percentage of alternative answers obtained reached 77.78 , this result assumes that the operational vehicle security mechanism within the Office of the Regional Secretariat of Gorontalo City has not been as expected. 5) The system of operational vehicle responsibility within the Office of the Regional Secretariat of Gorontalo City has not produced satisfactory results, this is supported by the percentage of alternative choice of normative answers only reaches $65.28 \%$.
\end{abstract}

Keywords: Analysis; Mechanism; Vehicle Operations.

\begin{abstract}
Abstrak
Penelitian ini bertujuan untuk mengetahui mekanisme penggunaan kendaraan operasional pada Kantor Sekretariat Daerah Kota Gorontalo serta Mengidentifikasikan usaha-usaha apa yang dilakukan Kantor Sekretariat Daerah Kota Gorontalo. Pendekatan penelitian yang digunakan adalah kuantitatif dan didukung dengan data primer dan data sekunder. Hasil penelitian menunjukan bahwa : 1) Mekanisme pemanfaatan kendaraan operasional di lingkungan Kantor Sekretariat Daerah Kota Gorontalo mencapai $78,33 \%$. 2) Mekanisme peminjaman kendaraan operasional di lingkungan Kantor Sekretariat Daerah Kota Gorontalo belum menampilkan hasil yang memuaskan.3) Merujuk pada capaian rata-rata sebesar $68,06 \%$, maka dapat diinterpretasikan bahwa mekanisme pembiayaan kendaraan operasional di lingkungan Kantor Sekretariat Daerah Kota Gorontalo belum seefektif dan seefisien seperti yang diharapkan. 4) Meninjau perolehan rata-rata persentase alternatif jawaban yang diperoleh mencapai 77,78, hasil ini mengasumsikan bahwa mekanisme pengamanan kendaraan operasional di lingkungan Kantor Sekretariat Daerah Kota Gorontalo belum sesuai harapan yang diinginkan. 5) Sistem pertanggungjawaban kendaraan operasional di lingkungan Kantor Sekretariat Daerah Kota Gorontalo belum menampilkan hasil yang memuaskan, hal ini didukung oleh angka persentase alternatif pilihan jawaban yang normatif hanya mencapai $65,28 \%$.
\end{abstract}

Kata kunci: Analisis; Mekanisme; Kendaraan Operasional. 


\section{PENDAHULUAN}

Arus informasi dan transportasi dalam berbagai hal menuntut adanya kesiapan dan ketersediaan sarana dan prasarana yang cukup untuk mendukung berbagai kegiatan dalam rangka pencapaian tujuan yang telah ditetapkan. Transportasi misalnya, merupakan salah satu alat penting yang mempunyai pengaruh besar terhadap perorangan, masyarakat, pembangunan ekonomi dan sosial politik suatu negara. Dapat dikatakan bahwa pengangkutan atau transportasi merupakan sarana penunjang bagi pembangunan ekonomi negara yang bisa mendorong lajunya pertumbuhan ekonomi. Menurut Salim (1993 ; hal.1) menjelaskan bahwa transportasi memegang peranan penting dalam usaha mencapai tujuan-tujuan pengembangan ekonomi. Adapun tujuan yang hendak dicapai dengan pengembangan ekonomi ialah :

1. Meningkatkan pendapatan nasional disertai dengan distribusi yang merata antar penduduk, bidangbidang usaha dan daerah-daerah.

2. Meningkatkan jenis dan jumlah barang jadi dan jasa yang dapat dihasilkan para konsumen, industri dan pemerintah.

3. Mengembangkan industri nasional yang dapat menghasilkan devisa serta mensupply pasaran dalam negeri

4. Menciptakan dan memelihara tingkatan kesempatan kerja bagi masyarakat.

Berdasarkan uraian di atas, jelaslah bahwa transportasi semestinya merupakan salah satu urat nadi dalam menyelesaikan berbagai pekerjaan secara efisien dan efektif. Namun demikian transportasi yang memadai akan mengakibatkan si pengguna transportasi tersebut tidak sadar atas kepemilikan kendaraan dan bahkan menyalahi prosedur dalam penggunaannya, sehingga fungsi kendaraan operasional tidak menyelesaikan pekerjaan secara efisien dan efektif lagi, melainkan akan menambah biaya operasional dan atau sebagai penghambat dalam pencapaian tujuan. Penggunaan-penggunaan yang diluar prosedur seperti ini akan menimbulkan masalah besar bagi institusi atau organisasi yang bersangkutan, yang secara otomatis akan berpengaruh pada pertumbuhan ekonomi.

Seperti halnya yang terjadi dalam dunia eksekutif atau pemerintahan dewasa ini, baik di tingkat Pusat sampai dengan di tingkat daerah Kota dan Kabupaten. Pengangkutan atau transportasi dalam lingkungan tersebut dikenal dengan sebutan kendaraan dinas atau kendaraan operasional, merupakan pendukung seluruh kegiatan guna pencapaian tujuan secara efisien dan efektif. Tanpa adanya kendaraan dinas, pemerintah dalam hal ini sebagai pelayan masyarakat akan lambat atau kurang responsif dalam melayani kebutuhan masyarakat. Olehnya kendaraan dinas dikatakan sebagai salah satu sarana penunjang yang penting dalam pemerintahan.

Kesepakatan mengenai penggunaan kendaraan dinas tersebut telah dibuat dan disusun dalam suatu aturan yang mengikat antara si pengguna kendaraan dinas dengan institusi yang bersangkutan guna pencapaian tujuan dalam hal ini pelayanan kepada masyarakat secara efisien dan efektif. Telah disepakati bahwa kendaraan dinas benar-benar dilakukan secara optimal untuk hal-hal yang bersifat kedinasan yang nantinya akan membawa hasil kerja pada institusi atau organisasi tersebut. Seperti 
halnya yang tertuang dalam Keputusan Menteri Dalam Negeri dan Otonomi Daerah, Nomor 11 tahun 2001, tentang Pedoman Pengelolaan Barang Daerah, yang menyebutkan bahwa pemanfaatan adalah pendayagunaan barang daerah oleh instansi dan atau pihak ketiga dalam bentuk pinjam pakai, penyewaan dan penggunausahaan tanpa merubah status kepemilikan. Dengan demikian pemanfaatan kendaraan dinas yang merupakan barang daerah benar-benar akan menghemat waktu, biaya dan tenaga dalam melayani masyarakat.

Namun kenyataan yang terjadi adalah masih banyak kendaraan dinas tersebut yang penggunaannya bukan untuk hal-hal yang bersifat kedinasan, melainkan hal-hal yang bersifat pribadi. Ini dibuktikan dengan masih beroperasinya kendaraan dinas di luar jam kerja. Dengan adanya kendaraan dinas di tempat-tempat parkir di pasar pada hari libur atau di tempat parkir di kafe pada malam hari misalnya, hal ini menimbulkan tanda tanya besar bagi masyarakat, bagaimanakah sebenarnya prosedur dari penggunaan kendaraan dinas tersebut dan apakah dengan beroperasinya kendaraan dinas tersebut akan membawa hasil bagi institusi yang bersangkutan dalam hal ini pemerintah, ataukah hanya digunakan untuk urusan pribadi dari si pengguna kendaraan dinas. Muncullah opini yang cenderung negatif di masyarakat terhadap si pengguna kendaraan dinas ini. Tetapi masyarakat tidak berani bertanya langsung dan tak paham harus kepada siapa mereka bertanya tentang hal ini.

Beberapa hal yang dapat di kaji secara ilmiah dari opini masyarakat ini sebagai bahan masukan kepada pemerintah, sehingga pemerintah dapat mengatur kembali kendaraan dinas ini sesuai aturan yang disepakati atau dapat meluruskan opini masyarakat yang negatif tentang penggunaan kendaraan dinas diluar jam kerja tersebut. Apabila dengan beroperasinya kendaraan dinas diluar jam kerja itu, benar-benar tidak membawa hasil bagi institusi yang bersangkutan, maka sudah seharusnya para pengambil kebijakan dari institusi atau organisasi tersebut mengambil langkah yang tepat, guna pencapaian tujuan yang telah direncanakan sebelumnya. Sesungguhnya bilamana beroperasinya kendaraan dinas diluar jam kerja itu sesuai prosedur dan aturan yang berlaku, tentu akan membawa hasil bagi institusi yang bersangkutan. Dalam artian kendaraan dinas yang dimiliki pemerintah tersebut telah benarbenar digunakan sesuai aturan yang telah disepakati, sebabnya apa yang dilakukan oleh pemerintah harus sepenuhnya didukung oleh masyarakat karena tanpa dukungan masyarakat, pemerintah tidak dapat merealisasikan apa yang telah direncanakan demi pencapaian tujuan dalam membangun negara ini. Masalah Pokok dalam penelitian ini sesuai dengan latar belakang dalam penulisan ini, adalah : Bagaimana mekanisme penggunaan kendaraan operasional pada Kantor Sekretariat Daerah Kota Gorontalo serta usaha-usaha apa yang dilakukan untuk mengefisiensikan penggunaan kendaraan operasional tersebut sesuai aturan yang ada.

\section{METODE PENELITIAN}

Berdasarkan permasalahan yang telah ditetapkan sebelumnya, maka yang menjadi daerah penelitian adalah Kota Gorontalo dengan obyek penelitian Kantor Sekretariat Daerah Kota Gorontalo. pendekatan penelitian menggunakan pendekatan kuantitatif. Adapun teknik pengumpulan data yang digunakan adalah sebagai berikut :

a. Angket, merupakan teknik pengumpulan data yang disusun 
dalam bentuk tulisan dengan menggunakan 4 (empat) alternatif pilihan dan sasarannya adalah pejabat yang memiliki mobil dinas di lingkungan Kantor Sekretariat Daerah Kota Gorontalo dan pihak lain yang terkait.

b. Wawancara, merupakan data yang diperoleh dari hasil tanya jawab langsung dengan pejabat yang memiliki mobil dinas di lingkungan Kantor Sekretariat Daerah Kota Gorontalo dan pihak lain yang bisa memberikan informasi

c. Observasi, merupakan data yang diperoleh dari hasil pengamatan di lapangan yang dilakukan peneliti saat penelitian pada Kantor Sekretariat Kota Gorontalo.

d. Dokumentasi, merupakan data yang diperoleh dari hasil dokumendokumen yang terkait dengan mekanisme penggunaan mobil dinas pada Kantor Sekretariat Daerah Kota Gorontalo.

e. Pustaka (library research), merupakan data yang diperoleh dari hasil literatur, serta catatan-catatan ilmiah lainnya yang berhubungan dengan masalah yang diteliti.

Data yang terkumpul lewat angket selanjutnya diolah dengan menggunakan analisis persentase yaitu :

$$
\mathrm{P}=\frac{\mathrm{f}}{\mathrm{n}} \times 100 \%
$$

dimana :

$$
\begin{aligned}
& \mathrm{P}=\text { Persentase } \\
& \mathrm{f}=\text { frekwensi responden } \\
& \mathrm{n}=\text { jumlah responden }
\end{aligned}
$$

Teknik analisis ini dimaksudkan untuk mengetahui secara jelas gambaran jawaban responden melalui pertanyaanpertanyaan yang terdapat dalam angket. Selanjutnya dengan menganalisis secara deskriptif atas mekanisme penggunaan kendaraan operasional dengan mengadakan perbandingan antara prosedur yang sebenarnya dan usaha-usaha yang di lakukan Kantor Sekretariat Daerah Kota Gorontalo guna mengefisiensikan penggunaan kendaraan operasional tersebut.

\section{HASIL DAN PEMBAHASAN}

Gambaran umum Lokasi

Kantor Sekretariat Daerah Kota Gorontalo dikepalai oleh seorang Sekretaris Daerah. Dimana Sekretaris Daerah tersebut diangkat oleh Gubernur Kepala Daerah atas nama Menteri Dalam Negeri, yang berasal dari pegawai negeri sipil yang telah memenuhi persyaratan, atas usulan Walikota Kepala Daerah, setelah mendengar pertimbangan Pimpinan Dewan Perwakilan Rakyat Daerah. Jadi Sekertaris Daerah tersebut berada dibawah dan bertanggung jawab langsung kepada Walikota sebagai Kepala Daerah.

Seperti apa yang dikemukakan oleh Widjaja (1992:213) bahwa Sekretaris Daerah mempunyai tugas yang sangat luas dan penting. Sebagai Kepala Sekretariat yang besar dan yang langsung dibawah pimpinan Kepala Daerah dalam hal ini Walikota. Sekretaris Daerah mempunyai tugas utama yaitu membantu Walikota dalam melaksanakan tugas penyelenggaraan pemerintahan, administrasi, organisasi dan tata laksana serta memberikan pelayanan administratif kepada seluruh perangkat daerah kota.

Adapun Kantor Sekretariat Daerah Kota Gorontalo ini mempunyai 4 (empat) fungsi utama. Demikian yang tercantum 
dalam peraturan daerah kota Gorontalo nomor 17 tahun 2000 tentang organisasi dan tata kerja sekretariat daerah dan sekretariat dewan perwakilan rakyat daerah kota Gorontalo serta sekretariat kecamatan dan kelurahan, bahwa sekretariat daerah mempunyai fungsi mengkoordinasikan perumusan kebijakan pemerintah daerah kota (1), penyelenggaraan administrasi pemerintahan (2), pengelolaan sumber daya aparatur, keuangan, prasarana dan sarana pemerintahan daerah kota (3), serta pelaksanaan tugas lain yang diberikan Walikota sesuai dengan tugas fungsinya (4).

Jadi jelas bahwa Sekretariat Daerah Kota Gorontalo merupakan "leher botol", yang mengawasi lalu lintas kegiatan administrasi daerah Kota Gorontalo, dan menjadi pusat informasi data yang diperlukan dalam perencanaan dan pelaksanaan suatu pekerjaan. Masa jabatan Sekretaris Daerah tidak ditentukan tenggang waktunya. Oleh karena itu, Sekretaris Daerah adalah satu-satunya perangkat daerah yang mengetahui tentang administrasi pemerintahan daerah.

Ada beberapa indikator yang digunakan dalam menilai mekanisme penggunaan kendaraan Dinas di Sekretariat Daerah Kota Gorontalo. Dalam penelitian ini beberapa yang digunakan ialah : Mekanisme Penggunaan; Mekanisme Peminjaman; Mekanisme Pengamanan; Mekanisme Pembiayaan dan Sistem pertanggung jawaban. Dari hasil olahan data dari setiap indicator tersebut telah memberikan gambaran secara mendetail dari lima hal yang menjadi obyek dalam penelitian ini, akan tetapi belum memberikan kesimpulan yang berarti apakah kelima indikator tersebut benarbenar sesuai dengan harapan. Oleh sebab itu untuk lebih mengakuratkan hasil penelitian ini, maka berikut ini diinterpretasikan secara lebih jelas capaian hasil dari kelima indikator yang telah disebutkan sebelumnya.

Proses interpretasi data ini yaitu dengan menggabungkan persentase alternatif jawaban $(\mathrm{a}+\mathrm{b})$ yang telah dipaparkan dalam tabel-tabel sebelumnya sebagai prioritas utama yang menjadi harapan peneliti. Sedangkan persentase alternatif lainnya adalah $(\mathrm{c}+\mathrm{d})$ memberikan gambaran kuantitatif yang tidak diharapkan terjadi dalam mekanisme penggunaan kendaraan operasional di lingkungan Kantor Sekretariat Daerah Kota Gorontalo.

Dari hasil yang ada pada table 1 memperlihatkan bahwa perolehan rata-rata pada tabel tersebut didapatkan persentase alternatif jawaban yang diharapkan mencapai 78,33 \%. Hasil ini mengasumsikan bahwa mekanisme pemanfaatan kendaraan operasional di lingkungan Kantor Sekretariat Daerah Kota Gorontalo belum sesuai harapan yang diinginkan. Selanjutnya pada Tabel 2 mengenai mekanisme peminjaman kendaraan operasional di lingkungan Kantor Sekretariat Daerah Kota Gorontalo belum menampilkan hasil yang memuaskan. Hal ini didukung oleh angka persentase alternatif pilihan jawaban a dan b yang hanya mencapai jawaban 49,48 \% .

Meninjau perolehan rata-rata pada tabel 3 didapatkan persentase alternatif jawaban yang diharapkan mencapai 77,78 $\%$. Hasil ini mengasumsikan bahwa mekanisme pengamanan kendaraan operasional di lingkungan Kantor Sekretariat Daerah Kota Gorontalo belum sesuai harapan yang diinginkan. Selanjutnya pada table 4 diperoleh hasil pada capaian rata-rata sebesar 68,06 \% tersebut, maka dapat diinterpretasikan bahwa mekanisme pembiayaan kendaraan operasional di lingkungan Kantor Sekretariat Daerah Kota Gorontalo belum 
seefektif dan seefisien seperti yang

diharapkan.

Tabel 1

Mekanisme Pemanfaatan

\begin{tabular}{llc}
\hline \multicolumn{1}{c}{ Sub Indikator } & \multicolumn{2}{c}{$\begin{array}{c}\text { Persentase Alternatif Pilihan } \\
(\mathrm{a}+\mathrm{b})\end{array}$} \\
\hline Penggunaan untuk kunjungan kerja & 75.00 & 25.00 \\
Frekuwensi Penggunaan & 75.00 & 25.00 \\
Waktu Penggunaan & 87.50 & 12.50 \\
Penggunaan Untuk Urusan Pribadi & 83.34 & 16.67 \\
Penggunaan di Luar Kota & 70.84 & 29.17 \\
\multicolumn{1}{c}{ Rata-Rata } & 78.33 & 21.67 \\
\hline
\end{tabular}

Sumber : Olahan Data Primer

Tabel 2

Mekanisme Peminjaman

\begin{tabular}{lll}
\hline \multicolumn{1}{c}{ Sub Indikator } & \multicolumn{2}{c}{$\begin{array}{c}\text { Persentase Alternatif Pilihan } \\
(\mathrm{a}+\mathrm{b})\end{array}$} \\
\hline Penggunaan di Luar jam Kerja & 54.17 & 45.83 \\
Nomor Kendaraan Pribadi & 16.67 & 83.33 \\
Penggunaan oleh orang lain & 91.67 & 8.33 \\
Perijinan tertulis/lisan & 62.50 & 37.50 \\
Perijinan tertulis pada jam kerja & 37.50 & 62.50 \\
Perijinan tertulis di luar jam kerja & 41.67 & 58.34 \\
Perijinan lisan untuk urusan dinas & 50.00 & 50.00 \\
Perijinan lisan urusan di luar dinas & 41.67 & 58.33 \\
\multicolumn{1}{c}{ Rata-Rata } & 49.48 & 50.52 \\
\hline
\end{tabular}

Sumber : Olahan Data Primer

Tabel 3

Mekanisme Pengamanan

\begin{tabular}{lll}
\hline \multicolumn{1}{c}{ Sub Indikator } & \multicolumn{1}{c}{$\begin{array}{c}\text { Persentase Alternatif Pilihan } \\
(\mathrm{a}+\mathrm{b})\end{array}$} & \multicolumn{1}{c}{$(\mathrm{c}+\mathrm{d})$} \\
\hline Pengecekan fisik administrasi & 100,00 & 0.00 \\
Tempat Parkir & 54,16 & 45,84 \\
Pengecekan Fisik Tiap Bulan & 79,17 & 20,83 \\
\multicolumn{1}{c}{ Rata-Rata } & 77,78 & 22,22 \\
\hline
\end{tabular}

Sumber : Olahan Data Primer

Tabel 4.

Mekanisme Pembiayaan

\begin{tabular}{lll}
\hline \multicolumn{1}{c}{ Sub Indikator } & \multicolumn{2}{c}{$\begin{array}{c}\text { Persentase Alternatif Pilihan } \\
(\mathrm{a}+\mathrm{b})\end{array}$} \\
\hline Pembiayaan Operasional & 91.67 & 8.33 \\
Alokasi Pembiayaan & 70.84 & 29.16 \\
Biaya Operasional Mencukupi & 41.66 & 58.34 \\
\multicolumn{1}{c}{ Rata-Rata } & 68.06 & 31.94 \\
\hline
\end{tabular}

Sumber : Olahan Data Primer 
Tabel 5

Sistem Pertanggungjawaban

\begin{tabular}{llc}
\hline \multicolumn{1}{c}{ Sub Indikator } & \multicolumn{2}{c}{$\begin{array}{c}\text { Persentase Alternatif Pilihan } \\
(\mathrm{a}+\mathrm{b})\end{array}$} \\
\hline Pertanggungjawaban di dalam Dinas & 75.00 & 25.00 \\
Pertanggungjawaban di Luar Dinas & 79.16 & 20.84 \\
Laporan Penggunaan tiap Bulan & 62.50 & 37.50 \\
Jadwal tiap Bulan & 29.17 & 70.83 \\
Laporan biaya tiap Bulan & 79.17 & 20.83 \\
Meknisme Pelaporan & 66.67 & 33.33 \\
\multicolumn{1}{c}{ Rata-Rata } & 65.28 & 34.72 \\
\hline
\end{tabular}

Sumber : Olahan Data Primer

Dari tabel 5 tersebut diperoleh sistem pertanggungjawaban kendaraan operasional di lingkungan Kantor Sekretariat Daerah Kota Gorontalo belum menampilkan hasil yang memuaskan. Hal ini didukung oleh angka persentase alternatif pilihan jawaban a dan $\mathrm{b}$ yang hanya mencapai jawaban $65,28 \%$. Analisa persentase yang telah disajikan dalam paparan data di atas memberikan gambaran secara kuantitatif mengenai tujuan yang ingin dicapai dalam penelitian ini.

Berdasarkan hasil olahan data hasil rata-rata mekanisme pemanfaatan kendaraan operasional di lingkungan Kantor Sekretariat Daerah Kota Gorontalo mencapai 78,33 \%. Angka persentase ini jika dikonsultasikan pada taraf penilaian kualitas secara umum (ditetapkan $78 \%$ ) berarti mekanisme pemanfaatan kendaraan operasional hampir memenuhi standar maksimal yang diharapkan.

Selanjutnya dari hasil analisis mekanisme peminjaman kendaraan operasional di lingkungan Kantor Sekretariat Daerah Kota Gorontalo belum menampilkan hasil yang memuaskan, hal ini didukung oleh angka persentase alternatif pilihan responden yang hanya mencapai jawaban 49,48 \%. Angka persentase ini jika dikonsultasikan pada taraf penilaian kualitas secara umum (ditetapkan $50 \%$ ) berarti mekanisme peminjaman kendaraan operasional belum memenuhi standar maksimal yang diharapkan. Kondisi ini didukung oleh data pada indikator peminjaman, dimana sebagian responden selalu menggunakan kendaraan dinas melalui prosedur peminjaman dan sebagian lagi yang menggunakan kendaraan dinas dengan tidak menggunakan prosedur peminjaman.

Untuk analisis mekanisme Pengamanan rata-rata pada tabel 28 didapatkan persentase alternatif jawaban yang diharapkan mencapai 77,78\%. Angka persentase ini jika dikonsultasikan pada taraf penilaian kualitas secara umum (ditetapkan 78\%) berarti mekanisme pengamanan kendaraan operasional di lingkungan Kantor Sekretariat Daerah Kota Gorontalo belum memenuhi standar maksimal yang diharapkan.

Selanjutnya untuk mekanisme Pembiayaan Analisis data merujuk pada capaian rata-rata sebesar $68,06 \%$, atau jika dikonsultasikan pada taraf penilaian kualitas secara umum (ditetapkan 68\%) berarti mekanisme pembiayaan kendaraan operasional di lingkungan Kantor Sekretariat Daerah Kota Gorontalo belum seefektif dan seefisien seperti yang diharapkan.

Selanjutnya hasil analisa memberikan angka rata-rata mekanisme pemanfaatan kendaraan operasional di lingkungan Kantor Sekretariat Daerah Kota Gorontalo mencapai 65,28 \%. Angka 
persentase ini jika dikonsultasikan pada taraf penilaian kualitas secara umum (ditetapkan $65 \%$ ) berarti mekanisme pertanggungjawaban kendaraan operasional belum menampilkan hasil yang memuaskan.

\section{PENUTUP}

\section{Kesimpulan}

Dari hasil pembahasan diatas dapat ditarik kesimpulan sebagai berikut :

1. Mekanisme penggunaan kendaraan operasional pada Kantor Sekretariat Daerah Kota Gorontalo belum berjalan maksimal. Hal ini dibuktikan dengan analisis data responden terhadap penerapan mekanisme pemanfaatan, mekanisme peminjaman, mekanisme pengamanan, mekanisme pembiayaan dan system pertanggungjawaban masih menunjukkan angka yang belum sesuai dengan yang diharapkan.

2. Usaha-usaha yang dilakukan pemerintah Kota Gorontalo untuk mengefisiensikan pengelolaan kendaraan operasional sangatlah geliat. Hal ini dibuktikan dengan banyak hal yang memuat tentang perencanaan, pelaksanaan dan monitoring serta evaluasi penggunaan kendaraan operasional ada dalam peraturan daerah serta peratuiran kepala daerah.

\section{Saran}

1. Mekanisme penggunaan kendaraan operasional masih perlu ditingkatkan lagi dengan cara menjalankan aturan secara komitmen dan konsisten.

2. Dibutuhkan penganggaran yang memadai untuk menjalankan mekanisme penggunaan kendaraan operasional di Kantor Sekretariat Daerah Kota Gorontalo tersebut.

3. Perlu adanya pengawasan yang ketat dalam menjalankan mekanisme penggunaan kendaraan operasional di Kantor Sekretariat Kota Gorontalo.

\section{DAFTAR PUSTAKA}

Djarwanto. 2001, Statistik Sosial Ekonomi, edisi 3. Yogyakarta : Penerbit BPFE

Keputusan Walikota Gorontalo Nomor 80, 2001. Petunjuk Pelaksanaan Peraturan Daerah Kota Gorontalo Nomor 17 Tahun 2000 Tentang Organisasi dan Tata Kerja Sekretariat Daerah dan Sekretariat DPRD Kota Gorontalo serta Sekretariat Kecamatan dan Kelurahan.

Pusat Pembinaan dan Pengembangan Bahasa Indonesia. 1994. Kamus Besar Bahasa Indonesia, edisi 2, Jakarta : Penerbit Balai Pustaka.

Salim H.A. Abbas. 1993. Manajemen Transportasi, edisi 1. Jakarta: Penerbit PT. Raja Grafindo Persada Subagyo Pangestu. 2000. Manajemen Operasi, edisi 1. Yogyakarta : Penerbit BPFE

Sugiyono. 2001. Metode Penelitian Administrasi, edisi 8. Bandung: Penerbit Alfabeta

Sukirno Sadono. 1981. Pengantar Teori Makro Ekonomi. Depok: Penerbit Lembaga Penerbit Fakultas Ekonomi Universitas Indonesia.

Teguh Muhammad. 2001. Metodologi Penelitian Ekonomi Teori dan Aplikasi, edisi 2. Jakarta : Penerbit PT. RajaGrasindo Persada

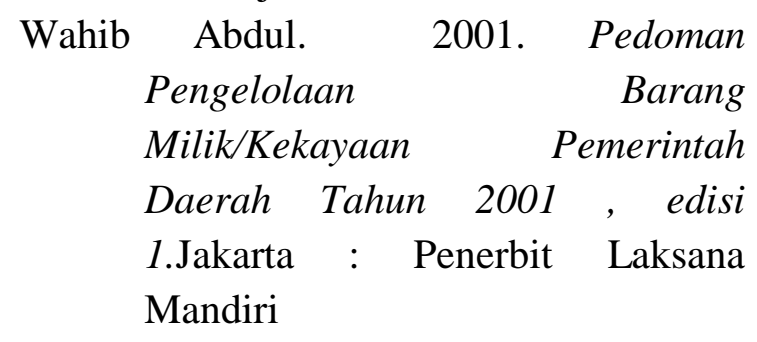

